İşletme Akademisi Dergisi
2020,1 (1): 77-87
DOI: $10.26677 / T R 1010.2020 .352$
Dergi web sayfasi: www.isakder.org

Araștırma Makalesi

\title{
Faiz Oranları, ABD Doları, Euro ve BIST 100'ün BIST Bankacılık Endeksi İle İlişkisi: Türkiye Üzerine Bir Uygulama
}

\author{
Arş. Gör. Bekir ZENGİN \\ Ankara Hacı Bayram Veli Üniversitesi, Bankacılık ve Sigortacılık Yüksekokulu, Bankacılık \\ Anabilim Dall, \\ bekir.zengin@hbv.edu.tr, www.orcid.org/0000-0001-7572-5290
}

\section{Öz}

Bu çalışmada; BIST Bankacılık Endeksinin (XBANK) faiz oranları, ABD Doları, Euro ve Borsa İstanbul (BIST 100) ile ilişkisi incelenmektedir. 2015 - 2018 yıllarına ilişkin günlük verilerin kullanıldığı çalışmada, söz konusu değişkenler arasındaki ilişki, çoklu doğrusal regresyon yöntemi ile incelenmektedir. Elde edilen sonuçlara göre; Bankacılık Endeksinin, ABD Dolar kuru ile negatif bir ilişkisi olduğu ve bu ilişkinin istatistiki olarak anlamlı olduğu, faiz oranı ile pozitif bir ilişkisi bulunduğu ve bu ilişkinin aynı şekilde istatistiki olarak anlamlı olduğu, Euro ile negatif bir ilişkisi olduğu ancak istatistiki olarak bu ilişkinin anlamlı olmadığı tespit edilmiştir. Son olarak Bankacılık endeksinin Borsa İstanbul ile pozitif bir ilişkisi bulunduğu ve bu ilişkinin istatistiki olarak anlamlı olduğu bulunmuştur.

Anahtar Kelimeler: Bankacılık Endeksi, Faiz Oranı, ABD Doları, Euro, BİST 100, Regresyon, Türkiye

Makale Gönderme Tarihi: 05.02.2020

Makale Kabul Tarihi: 11.03.2020

\section{Önerilen Atıf:}

Zengin, B., (2020). Faiz Oranları, ABD Doları, Euro ve BIST 100'ün BIST Bankacılık Endeksi İle İlişkisi: Türkiye Üzerine Bir Uygulama, İşletme Akademisi Dergisi, 1(1): 77-87.

(c) 2020 İşletme Akademisi Dergisi. 


\title{
Journal of Business Academy
}

2020, 1 (1): 77-87

DOI:10.26677/TR1010.2020.

Web pages: www.isakder.org

Research Article

\section{The Effect of Interest Rate, Us Dollar, Euro And BIST 100 on Banking Index: An Application on Turkey}

\author{
Research Assistant Bekir ZENGIN \\ Ankara Hacı Bayram Veli University, Vocational School of Banking and Insurance \\ bekir.zengin@hbv.edu.tr, www.orcid.org/0000-0001-7572-5290
}

\begin{abstract}
In this study; the relation of the BIST Banking Index with the interest rates, US Dollar, Euro and Borsa Istanbul (BIST 100) is examined. In the study, which uses the daily data for 2015 - 2018, the relationship among the variables used is tested by multiple linear regression analysis. According to findings, it was found that The Bist Banking Index had a negative relationship with U.S. Dollar and this relationship to be statistically significant, a positive relationship with the rate of interest and this relationship to be statistically $10 \%$ significant margin of error, a negative relationship with Euro but this relationship not to be statistically significant. Finally, it is found that the Bist Banking index has a positive relationship with Borsa Istanbul and this relationship is statistically significant.
\end{abstract}

Keywords: Banking Index, Interest Rates, US Dollar, Euro, BIST 100, Regression, Turkey

Received: 05.02.2020

Accepted: 11.03 .2020

\section{Suggested Citation:}

Zengin, B., (2020). The Effect of Interest Rate, Us Dollar, Euro And BIST 100 on Banking Index: An Application on Turkey, Journal of Business Academy, 1(1): 77-87.

(C) 2020 Journal of Business Academy. 


\section{GİRIŞ}

Borsa İstanbul'da yer alan şirketlere yapılan yatırımlar politik ve ekonomik koşullar başta olmak üzere pek çok faktörden etkilenmektedir. Bu faktörler ayrıca bankacıllk sektörü kapsamında bulunan şirketlerle ilgili yapılacak yatırımın miktarını ve süresini belirleme noktasında önemli rol üstlenmektedir. Bir ülkede enflasyonun düşük ya da yüksek olması, istihdam oranı, döviz kurunun düşük ya da yüksek olması ve siyasi istikrar gibi pek çok faktör o ülkedeki sermaye piyasalarına olan ilgiyi etkilemektedir. 1980'li yıllardan itibaren Türkiye ekonomisi liberalizasyon sürecini etkili bir şekilde yürütmektedir. Bilhassa mali piyasalarda etkisini hissettiren liberalizasyon süreci, döviz kurları ve faiz oranındaki dalgalanmalar reel ekonomi üzerinde etkili olmuştur. Döviz kuru ve faiz oranındaki oynaklıklar borsa getirisi üzerinde pek çok etkide bulunabilmektedir. Faiz oranındaki artışlar, döviz kuru tasarrufların Türk Lirası(TL) vadeli mevduat hesaplarına kaymasına neden olurken, borsadan ise fon çıkışana yol açabilmektedir. Faiz oranındaki düşüş̧ler ise yatırım maliyetlerini azalmakta, istihdam ve üretim olanaklarını artırmaktadır. Dolayısı ile bu durum ekonomik büyüme ve kalkınmaya yol açmaktadır. Döviz kurundaki değişmeler ise ihracat ve ithalat üzerinde etkisini hissettirmektedir. Döviz kurlarının düşük seyretmesi bir taraftan ithal mallarını düşük maliyetli hale getirerek ithalatın artmasına sebep olurken, diğer taraftan ihracatı azaltarak yerli malına olan talebi zayıflatmaktadır. Döviz kurlarının yüksek seyretmesi durumunda yerli malı ile ihracat yapan sektörlerin ihracat payında artışa yol açarken, üretim bazında yurtdışına bağımlı olan ve ihracat bazlı üretim yapan sektörlerde de üretim maliyetlerini yükseltmektedir.

Para ve sermaye piyasasında yabancı sermaye kontrolünün esnetilmesi ve esnek kur rejiminin uygulanması döviz kurları ile hisse senetleri arasındaki ilişkiyi daha hassas duruma getirmektedir. Geleneksel modelde Dornbush ve Fisher (1980), döviz kurunda meydana gelen değişimlerin daha çok para arzı ve para talebindeki dengesizliklerden kaynaklandığını ve döviz kurunda herhangi bir değişim gözlemlendiğinde bu durumun ülkenin rekabet gücünü ve diş ticaret dengesini değiştirerek ve ekonomideki reel gelir ve üretim miktarının bu durumdan etkileneceğini belirtmektedir. Stavarek (2005)'e göre, portföy dengesi yaklaşımında, hisse senetleri fiyatlarında meydana gelen bir artış yerli paranın değerini pozitif bir biçimde doğrudan ve dolaylı olarak etkileyerek yatırımciları yabancı menkul kıymetleri elden çıarmaya ve nihayetinde hisse senedi alımına yönlendirecektir. Bu durum yerli para talebini ve döviz arzını artırarak ulusal paranın değerinde artışa neden olmakta, döviz kurunun değerini düşürmektedir.

Bu çalışmada; faiz oranları, ABD doları, Euro ve Bist 100'ün bankacılık endeksi ile ilişkisi incelenmiştir. Bu doğrultuda, çalışma, beş kısımdan oluşmaktadır. Birinci kısımda, daha önce yapılmış çalışmalara yer verilmiştir. İkinci kısımda veri ve değişkenler tanımlamış, üçüncü kısımda çalışmada kullanılan yöntem hakkında bilgi verilmiştir. Dördüncü kısımda ampirik bulgular, son kısımda ise sonuç yer almaktadır.

\section{LITTERATÜR İNCELEMESİ}

Literatür incelemesinde, daha önce yapılmış olan çalışmalar aşağıda yer almaktadır. Söz konusu bu çalışmaların bir kısmı firma bazında bir kısmı da ülke bazında gerek Türkiye gerekse de yabancı ülkeler ile ilgili çalışmalardır.

Bae (1990) faiz oranındaki değişikliklerin hisse senedi getirilerine etkisini 1974-1985 yılları arasında aylık verilerle incelemiştir. Çalışmada hem cari faiz oranları hem de beklenmeyen (öngörülmeyen) faiz oranları kullanılmıştır. Çalışmada elde edilen bulgulara göre cari faiz oranındaki değişikliklerin firmaların hisse senedi getirilerini olumsuz etkilediği tespit edilirken, beklenmeyen faiz oranındaki değişikliklerin de firmaların hisse senedi getirileri üzerine 
etkisinin negatif olduğu bulunmuştur. Bu olumsuz etkiye, uzun dönemli faiz oranın sebep olduğu tespit edilmiştir.

Karamustafa ve Küçükkale (2002) Türkiye'de Kasım 2000 ve Şubat 2001 dönemini kapsayan zaman dilimi içerisinde döviz kurları, faiz oranları ve hisse senedi getirileri arasındaki ilişkiyi günlük veriler kullanarak Granger Nedensellik Testi ile analiz etmişlerdir. Engle-Granger nedensellik testi sonucunda İMKB, Dolar ve Faiz değişkenleri arasında uzun dönemli ilişki bulunmadığı tespit edilmiştir.

Erbaykal ve Okuyan (2007) pay senedi fiyatları ile döviz kuru ilişkisini araştırmak üzere 13 gelişmekte olan ülke üzerinde eşbütünleşme ve nedensellik testi uygulamışlardır. Elde edilen bulgular Çek C. Tayland ve Malezya'da döviz kurunun pay senedi fiyatlarını etkilemede uzun dönemde negatif bir etkiye sahip olduğunu; Meksika ve G. Kore'de ise pay senedi fiyatlarının döviz kuru üzerinde uzun dönemde negatif bir etkisi olduğunu göstermektedir. Nedensellik testi sonucunda hisse senedi fiyatları ile döviz kuru arasında Brezilya, G. Kore ve Malezya'da çift yönlü nedensellik elde edilirken; Macaristan, Filipinler Endonezya, Tayland ve Meksika'da pay senedi fiyatlarından döviz kuruna doğru tek yönlü nedensellik olduğu tespit edilmiştir. Çek C.Hindistan, Şili, Çin ve Türkiye'de ise değişkenler arasında herhangi bir nedensellik ilişkisine ulaşılmamıştır.

Alam ve Uddin (2009) gelişmiş ve gelişmekte olan 15 ülkenin faiz oranları ile pay senedi fiyatları arasındaki ilişkiyi Ocak 1988 - Mart 2003 dönemi aylık verilerle analiz etmiştir. Elde edilen bulgular, Malezya'nın faiz oranlarının hisse senedi fiyatları ile bir ilişkisi olmadığı ancak faiz oranlarındaki değişikliklerin hisse senedi fiyatlarındaki değişiklikler ile negatif ilişkili olduğunu göstermektedir. Japonya'da ise faiz oranının pay senedi fiyatları ile pozitif ilişkili olduğu fakat faiz oranındaki değişikliklerin pay senedi fiyatındaki değişikliklerle negatif ilişkili olduğu tespit edilmiştir. G. Afrika, İtalya, Bangladeş ve Kolombiya dâhil olmak üzere dört ülkenin hem pay senedi fiyatları ile faiz oranlarının hem de pay senedi fiyatlarındaki değişiklikler ile faiz oranları negatif ilişkili olduğu bulunmuştur. İspanya, Venezuela, Avustralya, Almanya, Şili, Meksika, Kanada, Jamaika olarak sıralanabilecek 8 ülkenin faiz oranları ile hisse senedi fiyatları arasında negatif ilişki tespit edilirken, faiz oranlarındaki değişiklikler ile hisse senedi fiyatlarındaki değişiklikler arasında herhangi bir ilişki bulunamamıştır. Sadece Filipin'de hem hisse senedi fiyatı ile faiz oranları arasında hem de faiz oranlarındaki değişiklikler ile hisse senedi fiyatlarındaki değişiklikler arasında anlamlı negatif bir ilişki tespit edilmiştir.

Savaş ve Can (2011) İstanbul Menkul Kıymetler Borsası'nda işlem gören pay senedi fiyatları ile Euro-Dolar paritesi ve reel efektif döviz kuru endeksi arasındaki ilişkiyi aylık verilerle Ocak 2000 - Temmuz 2009 dönemi için çoklu doğrusal regresyon modeli ve Granger nedensellik testi ile analiz etmişlerdir. Çalışmada elde edilen bulgular, hem reel efektif döviz kuru ile İMKB 100 endeksi arasında hem de Euro-Dolar paritesi ile İMKB 100 endeksi arasında pozitif bir ilişkinin olduğunu göstermektedir. Granger nedensellik sonuçlarına göre ise İMKB 100 endeksindeki bir değişme hem reel efektif döviz kurunu hem de Euro-Dolar paritesinin bir ay önceki değerini etkilediği tespit edilmiştir.

Büberkökü (2013) Almanya, Kanada, İsviçre, Avustralya, İngiltere ve Japonya gibi gelişmiş ülkeler ile Türkiye, Güney Kore ve Singapur gibi gelişmekte olan bazı ülkelerin pay senedi fiyatları ile döviz kurları arasındaki ilişkiyi incelemiştir. Çalışma kapsamında elde edilen bulgulara göre Kanada ve İsviçre'de pay senedi fiyatlarından döviz kurlarına doğru tek yönlü bir nedensellik ilişkisi elde edilirken; İngiltere, Almanya, Japonya ve Avustralya' da ise herhangi bir nedensellik ilişkisine ulaşılamamıştır. Gelişmekte olan ülkelere bakıldığında Singapur ve G. Kore'de döviz kurlarından pay senedi fiyatlarına doğru tek yönlü bir nedenselliğe rastlanırken; 
Türkiye'de sadece hisse senedi fiyatlarından döviz kurlarına doğru bir nedensellik ilişkisine rastlanmıştır. Söz konusu ülkeler içinde sadece Singapur'da pay senedi fiyatları ile döviz kurları arasında uzun dönemli ilişkiye rastlanmıştır.

Şentürk ve Dücan (2014) döviz kuru (dolar) ve faiz oranının BİST 100 getirisi üzerindeki etkisini Ocak 1997 - Mayıs 2013 dönemi için aylık verilerle incelemiştir. Elde edilen bulgular döviz kuru ve faiz oranının borsa getirisi ile negatif ilişkili ancak borsa getirisinin döviz kuruna daha duyarlı olduğunu göstermektedir. Ayrıca döviz kurundan borsa getirisine ve faiz oranından da döviz kuruna tek yönlü nedensellik ilişkisi bulunduğu tespit edilmiştir.

Kendirli ve Çankaya (2016) Türkiye kapsamında 2009:1 - 2015:3 dönemine ait aylık verilerle döviz kuru (dolar) ve enflasyondaki dalgalanmanın BİST bankacılık endeksini nasıl etkilediğini ekonometrik analizlerle test etmişlerdir. Çalışmada elde edilen bulgular, bankacılık endeksinden döviz kuruna tek yönlü nedensellik ilişkisi olduğunu ve diğer değişkenlerin birbiri ile herhangi bir nedensellik ilişkisi olmadığını göstermektedir.

Uyar, Kangallı Uyar ve Gökçe (2016) gösterge faiz oranı ile Borsa İstanbul endeksleri (BİST 100, BIST 30, BİST Mali, BİST Banka ve BİST Tüm Endeksler) arasındaki ilişkiyi Ocak 2006 - Ocak 2015 dönemi için analiz etmişlerdir. Bu doğrultuda endekslerin düşük ya da yüksek olduğu zamanlarda gösterge faizinde meydana gelen hareketlerin mali piyasaları nasıl etkilediği incelenmiştir. Çalışmada elde edilen bulgular gösterge faiz oranının, analize dâhil edilen tüm endekslerle negatif ilişkili olduğunu göstermektedir. Endekslerin yüksek seyrettiği dönemlerde negatif etkinin güçlendiği tespit edilmiştir. Analiz kapsamında gösterge faiz oranından en çok etkilenen endekslerin BİST Bankacılık ve BİST Mali olduğu bulunmuştur.

Coşkun ve Yener (2016) BİST 100 hisse senedi endeksi getirisi ile döviz kuru, altın fiyatı, mevduat faiz oranı ve reel konut fiyat endeksi arasındaki uzun dönemli ilişkiyi 2000:01 2014:07 dönemine ait aylık veriler kullanarak eşbütünleşme yöntemiyle analiz etmişlerdir. Elde edilen sonuçlar BİST 100 hisse senedi getirisi ile döviz kuru, altın fiyatı, mevduat faiz oranı ve konut fiyatlarının uzun dönemde eşbütünleşme ilişkisi içerisinde olduğunu göstermektedir. Maki testi sonucunda ise seriler arasında herhangi bir uzun dönemli ilişki olmadığ gözlemlenmiştir.

Eyüpoğlu ve Eyüpoğlu (2018) Borsa İstanbul endeksleri ile döviz kurları arasındaki ilişkiyi 03/01/2011 - 26/05/2016 dönemi için analiz etmişlerdir. Çalışmada BİST 100 endeksi ve 23 sektöre ait pay senedi endeksleri ile Dolar ve Euro döviz kurlarına ilişkin günlük veriler incelenmiştir. Elde edilen bulgular, endeksten sadece BIST Tekstil Deri endeksi ile Euro döviz kuru arasında, Dolar kuru ile BIST Tekstil Deri ve Ticaret ve Teknoloji endeksleri arasında uzun dönemli ilişki olduğunu göstermektedir.

Literatür incelemesine bakıldığında çalışmaların çoğu faiz oranları, hisse senedi, kur (genellikle Dolar ve Euro) ve borsa üzerine olduğu görülmektedir. Çalışmalara bakıldığında faiz oranlarının hisse senedi getirilerine etkisinin negatif olduğu, Dolar/Euro kurunun Bist 100 ile pozitif ilişkisi olduğu, Döviz kuru ve faiz oranın Borsa ile negatif etkileşimi olduğu ve son olarak faiz oranının Bist bankacılık ile negatif ilişkili olduğu görülmektedir.

\section{VERI VE DEĞIŞKENLERIN TANIMLANMASI}

2015 - 2018 dönemine ilişkin günlük verilerin kullanıldığı bu çalışmada, Türkiye'de faiz oranları, ABD Doları (ABD Doları/TL), Euro (Euro/TL) ve Bist 100'ün Bankacılık endeksi ile ilişkisi çoklu doğrusal regresyon analizi ile incelenmiştir. Çalışmada günlük verilerden yararlanılmış ve tüm verilerin yüzdelik değiş̧imi alınarak analiz yapılmıştır. 
Tablo 1'de çalışmada kullanılan değişkenlerin açıklamaları, kullanılan zaman aralığı ve temin edilen kaynak sunulmaktadır.

Tablo 1. Değişkenlerin Tanımlanması

\begin{tabular}{|c|c|c|c|}
\hline Değişken & Açıklama & Zaman Aralığ1 & Kaynak \\
\hline XBANK & $\begin{array}{l}\text { Bankacılık Endeksi } \\
\text { Yüzdesel Değişimi }\end{array}$ & $\begin{array}{c}02 / 01 / 2015- \\
31 / 12 / 2018\end{array}$ & www.bloomberg.com \\
\hline USDTRY & $\begin{array}{l}\text { ABD Doları TL Paritesi } \\
\text { Yüzdesel Değişimi }\end{array}$ & $\begin{array}{c}02 / 01 / 2015- \\
31 / 12 / 2018 \\
\end{array}$ & www.bloomberg.com \\
\hline EURTRY & $\begin{array}{c}\text { Euro TL Paritesi Yüzdesel } \\
\text { Değişimi }\end{array}$ & $\begin{array}{c}02 / 01 / 2015- \\
31 / 12 / 2018 \\
\end{array}$ & www.bloomberg.com \\
\hline MBAOFO & $\begin{array}{c}\text { Merkez Bankası Ağırlıklı } \\
\text { Ortalama Faiz Oranı } \\
\text { Yüzdesel Değişimi }\end{array}$ & $\begin{array}{l}02 / 01 / 2015- \\
31 / 12 / 2018\end{array}$ & www.bloomberg.com \\
\hline BİST100 & $\begin{array}{c}\text { Borsa İstanbul Endeksi } \\
\text { Yüzdesel Değişimi }\end{array}$ & $\begin{array}{l}02 / 01 / 2015- \\
31 / 12 / 2018\end{array}$ & www.bloomberg.com \\
\hline
\end{tabular}

Analizde kullanılan değişkenlerin tanımlayıcı istatistiki değerleri ve korelasyon matrisi Tablo 2 'de sunulmuştur.

Tablo 2. Tanımlayıcı İstatistikler

\begin{tabular}{|c|c|c|c|c|c|}
\hline & XBANK & USDTRY & MBAOFO & EURTRY & BÍST100 \\
\hline Ortalama & $-0,0112$ & 0,0880 & 0,3711 & 0,0826 & 0,0145 \\
\hline Medyan & $-0,0790$ & 0,0338 & 0,0000 & 0,0514 & 0,0527 \\
\hline Maksimum & 9,3590 & 15,8848 & 127,3421 & 14,6329 & 5,3956 \\
\hline Minimum & $-9,7833$ & $-7,7515$ & $-32,3694$ & $-8,2530$ & 7,0845 \\
\hline Standart Sapma & 1,9324 & 1,1379 & 8,2974 & 1,1391 & 1,2833 \\
\hline Gözlem Sayısı & 1002 & 1002 & 1002 & 1002 & 1002 \\
\hline
\end{tabular}

Tablo 3'te Pearson korelasyon matrisi verilmiştir. Pearson katsayısı, iki değişken arasındaki doğrusal ilişkinin kuvveti ve yönü hakkında bilgi vermekte ve değeri $-1 \leq \mathrm{r} \leq 1$ arasında değişmektedir. Tabloya göre Bankacılık endeksinin Dolar kuru ile negatif bir ilişkisi, faiz oranı ile pozitif zayıf bir ilişkisi, Euro ile negatif bir ilişkisi ve Bist 100 ile pozitif kuvvetli bir ilişkisi olduğu görülmektedir.

Tablo 3. Pearson Korelasyon Matrisi

\begin{tabular}{|l|c|c|c|c|c|}
\hline & XBANK & USDTRY & MBAOFO & EURTRY & BIST100 \\
\hline XBANK & 1 & -0.4164 & 0.0048 & -0.3827 & 0.9158 \\
\hline USDTRY & -0.4164 & 1 & 0.0123 & 0.8703 & -0.3477 \\
\hline MBAOFO & 0.0048 & 0.01232 & 1 & 0.0464 & 0.0075 \\
\hline EURTRY & -0.3827 & 0.8703 & 0.0464 & 1 & -0.3176 \\
\hline BIST100 & 0.9158 & -0.3477 & 0.0075 & -0.3176 & 1 \\
\hline
\end{tabular}

\section{METODOLOJI}

Faiz oranları, ABD Doları, Euro ve Bist 100'ün Bist Bankacılık endeksi üzerindeki etkisini incelemek üzere çalışmada kullanılan model aşağıda sunulmaktadır:

$$
X B A N K=\beta_{0}+\beta_{1} U S D T R Y+\beta_{2} \text { MBAOFO }+\beta_{3} \text { EURTRY }+\beta_{4} \text { BIST } 100+\varepsilon
$$

Burada XBANK, bağımlı değişkeni; $\beta_{0}$, bağımsız değişkenlerin sıfır olması halinde bağımlı değişkenin alacağ değeri; $\beta_{1}, \beta_{2}, \beta_{3}$ ve $\beta_{4}$ hata terimi $\varepsilon^{\prime}$ nin ifade ettiği faktörler sabit iken 
bağımsız değişkenlerdeki bir birimlik değişme karşısında bağımlı değişkenin ne kadar değişeceğini göstermektedir.

Çalışmada faiz oranları, ABD Doları, Euro ve Bist 100'ün Bankacılık endeksi ile ilişkisini incelemek üzere çoklu doğrusal regresyon modeli kurularak analiz yapılmıştır. Gujarati (2004), regresyon modellerini bir bağımlı değişkenin bir veya daha fazla bağımsız değişken ile açıklayan modeller olarak tanımlamıştır. Ekonomide ve finans biliminde kurulan ilişkilerin modellenebilmesi bazı varsayımların geçerliliğine dayanmaktadır. Değişkenlerin doğrusal olarak ele alındığı regresyon modellerinde verilerin normal dağılıma sahip olduğu, birbiri ile çoklu doğrusal bağlantı içermediği, değiş̧en varyans ve otokorelasyon problemi bulunmadığ durumda kurulan regresyon modelleri sağlıklı bir şekilde yorumlanabilmektedir. Söz konusu bu varsayımlar sağlandığında kurulan modeller en küçük kareler (EKK veya OLS) metoduyla tahmin edilmektedir.

Basit doğrusal regresyon modeli bağımlı değişkenin, tek bir açıklayıcı değişken ve hata teriminin doğrusal fonksiyonu olduğu modeldir (Wooldridge, 2013: 580). Bağımlı değişkeni açılayan diğer değişkenlerin etkisinin çok küçük olduğu veya bilinmediği durumlarda bu model kullanılmaktadır (Sarıkovanlık ve diğeleri, 2019: 48). Çoklu doğrusal regresyon modeli ise bağımlı değişkeni, açıklayıcı değişkenlerin fonksiyonu ve hata terimi olduğunda parametrelere göre doğrusal olan modeldir (Wooldridge, 2013: 581). Çok değişkenli regresyon modelleri ile iki ya da daha fazla veri ile bir finansal veri açıklanabilmektedir. Herhangi bir bağımlı değişkeni hangi değişken ya da değişkenlerin etkilediğini ortaya çıkarmak ve ileriye yönelik tahminlerde bulunmak için çok değişkenli regresyon modeli kullanılabilmektedir (Sarıkovanlık ve diğeleri, 2019: 49).

1 no.lu denklemdeki ekonometrik modelin regresyon analizinin yapılabilmesi için tüm değişkenlerin trendden arındırılması gerekmektedir. Değişkenler durağan hale getirilmeden yapılan testlerin sonuçları hatalı olacağından istemeden yanlış yorumların yapılmasına sebep olacaktır. Bundan dolayı değişkenler arasında anlamlı ilişkiler elde edebilmek için serilerin durağan olması gerekmektedir. Zaman serisi modellerinde elde edilen rassal süreç zamanla sabitse seri durağan olmaktadır. Brooks (2008)'a göre durağan zaman serileri her gecikmeli değer için sabit bir ortalamaya, sabit bir varyansa ve sabit bir otokovaryansa sahip olmalıdır.

Çoklu regresyon analizi için E-Views paket programından yararlanılmıştır.

\section{AMPIRIKK BULGULAR}

Bu çalışmanın temel amacı; Bist Bankacılık Endeksinin faiz oranları, ABD Doları, Euro ve Bist 100 ile ilişkisini çoklu regresyon analizi ile incelemektir. Çoklu regresyon analizinin uygulanması sürecinde, aşağıdaki adımlar takip edilmiştir:

I. Serilerin durağanlıklarının incelenmesi

II. Değişkenler arasında çoklu regresyon analizinin gerçekleştirilmesi

III. En küçük kareler varsayımlarının incelenmesi

IV. Tahmin edilen katsayıların yorumlanması

Çalışmada herhangi bir sahte regresyon ilişkisinden kaçınmak için değişkenlerin bütünleşme derecelerinin incelenmesi amaciyla Augmented Dickey Fuller (ADF) birim kök testi uygulanmiştır.

Regresyon analizi öncesinde, serilerin durağanlık sınaması için gerçekleştirilen birim kök testi Tablo 4'de yer verilmektedir. XBANK, USDTRY, MBAOFO, EUROTRY ve BİST100 değişkenlerine ilişkin test istatistikleri hem sabitli hem de sabitli ve trendli modelde Mackinnon eşik değerinden küçük olduğundan söz konusu değişkenler seviye değerinde durağandır. 
B. Zengin, 1 (1): 77-87

Tablo 4. ADF Birim Kök Testi

\begin{tabular}{|c|c|c|}
\hline \multicolumn{3}{|c|}{ ADF Test İstatistiği } \\
\hline \multicolumn{3}{|c|}{ Düzey } \\
\hline Değişken & Sabit & Sabit ve Trend \\
\hline XBANK & $-13,46^{* * *}$ & $-13,46^{* * *}$ \\
\hline USDTRY & $-20,74^{* * *}$ & $-20,73^{* * *}$ \\
\hline MBAOFO & $-12,67^{* * *}$ & $-12,70^{* * *}$ \\
\hline EURTRY & $-20,46^{* * *}$ & $-20,45^{* * *}$ \\
\hline BİST100 & $-13,91^{* * *}$ & $-13,91^{* * *}$ \\
\hline & & $-3,97$ \\
\hline$\% 1$ & $-3,43$ & $-3,41$ \\
\hline$\% 5$ & $-2,86$ & $-3,13$ \\
\hline
\end{tabular}

Not: ${ }^{* *} \% 1, * * \% 5$ ve * \%10 hata düzeylerinde birim kökün varlığına dair boş hipotezin reddedildiğini göstermektedir. Birim kök testi Akaike Bilgi Kreiterine (AIC) dayalı ve maksimum gecikme uzunluğu 21'dir.

Serilerin durağanlık analizinin ardından değişkenler arasında ilişkinin incelenmesinde kullanılacak çoklu doğrusal regresyon analizinin seçilmesi gerekmektedir. Gerçekleştirilen regresyon testinin sonuçları Tablo 5'de sunulmaktadır.

Tablo 5. Çoklu Doğrusal Regresyon Testi Sonuçları

\begin{tabular}{|c|c|c|}
\hline \multicolumn{3}{|c|}{ Bağımlı Değişken: XBANK } \\
\hline & Katsayı & t-istatistiği \\
\hline C & $-0,0135$ & $-0,5652$ \\
\hline USDTRY & $-0,1452$ & $-3,3857^{* * *}$ \\
\hline MBAOFO & 0,0002 & $-0,0564^{*}$ \\
\hline EURTRY & $-0,0509$ & $-1,2004$ \\
\hline BIST100 & 1,3199 & $66,9172^{* * *}$ \\
\hline & Tanısal Test Sonuçları & \\
\hline$R^{2}$ & 0,8498 & \\
\hline Adjusted R & 0,8482 & \\
\hline F-istatistiği & $1410,29^{* * *}$ & \\
\hline D-W stat & 2,0450 & \\
\hline
\end{tabular}


B. Zengin, 1 (1): 77-87

\begin{tabular}{|l|l|}
\hline LM & $0,3572(0,6997)$ \\
\hline NORM & $1105,10(0,0000)$ \\
\hline HET & $0,4786(0,7515)$ \\
\hline RESET & $1,9669(0,0505)$ \\
\hline
\end{tabular}

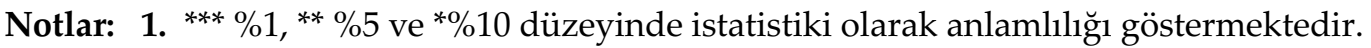

2. LM, otokorelasyon testi; NORM, normal dağılım testi; HET, değişen varyans testi; RESET, model tanımlama testidir. Tanısal testler için olasılık (p) değerleri parantez içinde belirtilmiştir.

Tablo 5 incelendiğinde ABD Dolar kuru ile Bankacılık Endeksi arasında negatif bir ilişki mevcut ve istatistiki olarak \%1 hata payında anlamlı olduğu görülmektedir. Diğer bir değişle, diğer değişkenler sabit iken USDTRY değişkeninde meydana gelen bir birimlik değişkenlik XBANK değişkenini yaklaşık olarak -0,15 birim etkilemektedir. Merkez Bankası Ağırlıklı Ortalama Faiz Oranı ile Bankacılık Endeksi arasında pozitif bir ilişki var, ancak istatistiki olarak \%10 hata payında anlamlıdır. Yani, diğer değişkenler sabit iken MBAOFO değişkeninde meydana gelen bir birimlik değişkenlik XBANK değişkeni 0,0002 birim etkilemektedir. EURO ile Bankacılık Endeksi arasında ise negatif bir ilişki mevcut, ancak bu ilişki istatistiki olarak anlamlı değildir. Son olarak BIST100 ile Bankacilık Endeksi arasında pozitif bir ilişki mevcut ve bu ilişki \%1 hata payında anlamlı olduğu görülmektedir. Diğer bir değişle, diğer değişkenler sabit iken BIST100 değişkeninde meydana gelen bir birimlik değişkenlik XBANK değişkeninde yaklaşık olarak 1,32 birimlik artışa yol açmaktadır. Tüm bu sonuçlar göz önünde bulundurulduğunda belirlilik katsayısına $\left(R^{2}\right)$ göre, BIST Bankacılık endeksindeki değişkenliğin yaklaşık \%85'i USDTRY, MBAOFO, EURTRY ve BIST100 testi sonuçlarındaki değişkenlikle açıklanabilmektedir.

Tablo 5'in alt kısmında regresyon testine ilişkin tanısal testler yer almaktadır. Tanısal testler incelendiğinde normal dağılım testi dışında diğer testler, \%5 hata payında, tahminin geçerli olduğu görülmektedir. Başka bir ifadeyle, otokorelasyona, değiş̧en varyansa ve model tanımlama hatası bulunduğuna dair bir kanıt bulunmamaktadır.

Ayrıca analize dâhil edilen değişkenlerin birbirleri üzerinde etkilerinin olup olmadığını kontrol etmek amacıyla çoklu doğrusal bağlantı ilişkisine bakılmaktadır. Bunun yapılabilmesi için Variation Inflation Factor (VIF, Varyans Artış Faktörü) değerlerinin incelenmesi gerekmektedir. VIF, bir bağımsız değişkenin başka bir bağımsız değişken ile olan ilişkisini belirlemek amacıyla kullanılmaktadır. Bu testin sonuçları aşağıda Tablo 6'da sunulmaktadır. Buna göre bağımsız değişkenler arasındaki korelasyon katsayısı 10'dan küçük olduğundan söz konusu değişkenler için çoklu doğrusal bağlantı probleminden söz edilememektedir.

Tablo 6. Varyans Artış Faktör Testi (VIF)

\begin{tabular}{|c|c|c|c|}
\hline & $\begin{array}{c}\text { Coefficient } \\
\text { Variance }\end{array}$ & $\begin{array}{c}\text { Uncentered } \\
\text { VIF }\end{array}$ & $\begin{array}{c}\text { Centered } \\
\text { VIF }\end{array}$ \\
\hline C & 0,0006 & 1,0001 & NA \\
\hline USDTRY & 0,0018 & 4,2591 & 1,0057 \\
\hline MBAOFO & $8,22 \mathrm{E}-06$ & 1,0077 & 1,0057 \\
\hline EURTRY & 0,0018 & 4,1712 & 4,1494 \\
\hline BIST100 & 0,0004 & 1,1391 & 1,1389 \\
\hline
\end{tabular}




\section{SONUÇ}

Bu çalışma; Bankacılık endeksinin faiz oranları, ABD Doları, Euro ve Borsa İstanbul (Bist 100) ile ilişkisini incelemektedir. 2015 - 2018 yıllarına ilişkin günlük verilerin kullanıldığı çalışmada, söz konusu değişkenler arasındaki ilişki, çoklu doğrusal regresyon analizi ile test edilmektedir. Elde edilen bulgulara göre ABD Dolar kuru ile Bankacılık endeksi arasında negatif bir ilişki mevcut ve istatistiki olarak \%1 hata payında anlamlı olduğu görülmektedir. Diğer bir deyişle, diğer değişkenler sabit iken ABD Dolar kuru değişkeninde meydana gelen bir birimlik değişkenlik Bankacılık endeksi değişkenini yaklaşık olarak -0,15 birim etkilemektedir. Merkez bankası ağırlıklı ortalama faiz oranı ile bankacılık endeksi arasında pozitif bir ilişki var, ancak istatistiki olarak \%10 hata payında anlamlıdır. Yani, diğer değişkenler sabit iken Merkez bankası Ağırlıklı Ortalama Faiz Oranı değişkeninde meydana gelen bir birimlik değişkenlik Bankacılık endeksi değişkeni 0,0002 birim etkilemektedir. EURO ile Bankacılık endeksi arasında ise negatif bir ilişki mevcut, ancak bu ilişki istatistiki olarak anlamlı değildir. Son olarak Borsa İstanbul ile Bankacılık endeksi arasında pozitif bir ilişki mevcut ve bu ilişki \%1 hata payında anlamlı olduğu görülmektedir. Yani, diğer değişkenler sabit iken Borsa İstanbul değişkeninde meydana gelen bir birimlik değişkenlik Bankacılık endeksi değişkeninde yaklaşık olarak 1,32 birimlik artışa yol açmaktadır.

Uyar, Kangallı Uyar ve Gökçe (2016) gösterge faiz oranı ile Borsa İstanbul endeksleri (BISTT 100, BİST 30, BİST Mali, BİST Banka ve BİST Tüm Endeksler) arasındaki ilişkiyi inceledikleri çalışmada faiz oranı ile Bist Bankacılık endeksi arasında negatif bir ilişki olduğu tespit edilmiştir. Bankacılık endeksinin faiz oranları, ABD Doları, Euro ve Borsa İstanbul (Bist 100) ile ilişkisinin incelendiği bu çalışmada ise faiz oranı ile Bist Bankacılık endeksi arasında pozitif bir ilişki olduğu gözlemlenmiştir. Literatür çalışmasının aksi yönünde elde edilen bu sonuca çalışmaların yapıldığı dönemin etkisi sebep olmuş olabilir. Ayrıca Uyar, Kangallı Uyar ve Gökçe (2016) çalışmalarında gösterge faizi kullanırken Bankacılık endeksinin faiz oranları, ABD Doları, Euro ve Borsa İstanbul (Bist 100) ile ilişkisinin incelendiği bu çalışmada ise Merkez Bankası Ağırlıklı Ortalama Faiz Oranı kullanılmıştır. Bundan dolayı da aksi yönde bir ilişki ortaya çıkmış olabilmektedir.

\section{KAYNAKÇA}

Alam, M. and Uddin, S. (2009). Relationship between Interest Rate and Stock Price: Empirical Evidence from Developed and Developing Countries. International Journal of Business and Management, 4 (3), 43-51.

Bae, S. C. (1990). Interest Rate Changes and Common Stock Returns of Financial Institutions: Revisited. The Journal of Financial Reserach, 13 (1), 71-79, https://doi.org/10.1111/j.14756803.1990.tb00537

Brooks, C. (2008). Introductory Econometrics for Finance, 2.ed., New York: Camridge University, 318.

Büberkökü, Ö. (2013). Hisse Senedi Fiyatları ile Döviz Kurları Arasındaki İlişkinin İncelenmesi: Gelişmiş ve Gelişmekte Olan Ülkelerden Kanıtlar. İstanbul Menkul Kıymetler Borsası, 13 (52), 1-17, ISSN: 1301-1650

Dornbush R. And Fisher S. (1980). Exchange Rates and the Current Account. American Economic Review, 70, 960-971. 
Erbaykal, E. ve Okuyan, H.AA. (2007). Hisse Senedi Fiyatları ile Döviz Kuru İlişkisi: Gelişmekte Olan Ülkeler Üzerine Ampirik Bir Uygulama. Bankacılı Denetleme ve Düzenleme Kurulu Bankacilık ve Finansal Piyasalar Dergisi, 1 (1), 77-89.

Eyüpoğlu, S. ve Eyüpoğlu, K. (2018). Borsa İstanbul Sektör Endeksleri ile Döviz Kurları Arasındaki İlişkilerin İncelenmesi: ARDL Modeli. Ömer Halisdemir Üniversitesi İktisadi ve İdari Bilimler Fakültesi Dergisi, 11 (1), 8-28.

Gujarati, D. (2004). Basic Econometrics, United States Military Academy, West Point.

Karamustafa, O. ve Küçükkale, Y. (2002). Türkiye'de Kriz Döneminde Kur-Faiz-Borsa İlişkilerinin Dinamik Analizi. Banka-Mali ve Ekonomik Yorumlar, (11), 47-56.

Kendirli, S. ve Çankaya, M. (2016). Döviz Kuru ve Enflasyonun BİST Banka Endeksi Üzerindeki Etkisi. MANAS Sosyal Araşttrmalar Dergisi, 5 (3), 215-227.

Sarıkovanlık, V., Koy, A., Akkaya, M., Yıldırım, H. H. ve Kantar, L. (2019). Finans Biliminde Ekonometri Uygulamaları Kavram-Uygulama-Analiz, Ankara: Seçkin Yayıncllık, ISBN 978975-02-5331-7.

Savaş, İ. ve Can, İ. (2011). Euro-Dolar Paritesi ve Reel Döviz Kuru'nun İMKB 100 Endeksi'ne Etkisi. Eskişehir Osmangazi Üniversitesi İktisadi ve İdari Bilimler Fakültesi Dergisi, 6 (1), 323339.

Stavarek D. (2005). Linkages between Stock Prices and Exchange Rates in the EU and the United States. Czech Journal of Economics and Finance, 55 (3-4), 141-161.

Şentürk, M. ve Dücan, E. (2014). Türkiye'de Döviz Kuru-Faiz Oranı ve Borsa Getirisi İlişkisi: Ampirik Bir Analiz. Business and Economics Research Journal, 5 (3), 67-80.

Uyar, U., Kangallı Uyar, S. ve Gökçe, A. (2016). Gösterge Faiz Oranı Dalgalanmaları ve BíST Endeksleri Arasındaki İlişkinin Eşanlı Kantil Regresyon ile Analizi. Ege Akademik Bakış Dergisi, 16 (4), 587-598.

Wooldridge, J.M. (2009). Ekonometriye Giriş: Modern Yaklaşım. Çağlayan, E. (Çev). Ankara: Nobel Akademik Yayıncılık Eğitim Danışmanlık. 